Pendas : Jurnal IImiah Pendidikan Dasar, ISSN Cetak : 2477-2143 ISSN Online : 2548-6950 Volume III Nomor 2, Desember 2018

\title{
PENGEMBANGAN BUKU AJAR BAHASA INDONESIA BERBASIS PENDIDIKAN KARAKTER DENGAN MODEL ASSURE PADA SISWA SEKOLAH DASAR
}

\author{
Antonius Alam Wicaksono', Hanif Fikri Bariska² \\ 1,2PGSD FIP Universitas Tribhuwana Tunggadewi) \\ 1antoniuseducator@gmail.com, ${ }^{2}$ hanif.fikrib@gmail.com
}

\begin{abstract}
Text book is material used by the students for helping the achievement of the competency standard, the purpose of education of primary and competence have (Depdiknas.2006). Of research, development text book based character education with a assure model on primary school student aimed at for (1) know the process of development text book Indonesian language based character education by using assure kind of classroom in primary school student, (2) know the quality of teks book Indonesian language based character education by using assure kind of classroom in primary school student. This research using kind of research development (research and development). A design study on four-D oriented model consisting of 4 steps in the define, design, develop, and disseminate. Data collection techniques used in the process of define used technique documentation main competence (KI) and basic competence (KD) in 2013 curriculum. Data collection techniques used in the process of design validation the technique, observation, the survey, and tests used to measure product quality based on terms of use.The result of developing teks book based character education with a assure model on primary school student that have been validated to the quality of the books according to components teaching material, the appearance of, language and graphic reached the percentage of the respective components $98,9 \%, 100 \%, 96,4 \%, 94,8 \%$. The result of the observation for the use of the activity of teachers text book components, the activity of students and response students show the percentage of the respective components $93.5 \%, 93,75 \%$, statements of some $91.7 \%$; and for the results of character of students to being honest, responsibility, tolerance and work together in a row the scores were $4,4,4$ and 3 .
\end{abstract}

Keywords: textbook, character education, ASSURE model 
Pendas : Jurnal IImiah Pendidikan Dasar,

\section{ABSTRAK}

Buku teks adalah bahan yang digunakan oleh siswa untuk membantu pencapaian standar kompetensi, tujuan pendidikan dasar dan kompetensi inti (Depdiknas.2006). Dari penelitian, pengembangan buku teks berbasis pendidikan karakter dengan model asure pada siswa sekolah dasar bertujuan untuk (1) mengetahui proses pengembangan buku teks pendidikan karakter berbasis bahasa Indonesia dengan menggunakan jenis jaminan kelas pada siswa sekolah dasar, (2) tahu kualitas teks buku pendidikan karakter berdasarkan bahasa Indonesia dengan menggunakan jenis jaminan kelas pada siswa sekolah dasar. Penelitian ini menggunakan jenis penelitian pengembangan (research and development). Sebuah studi desain pada model berorientasi empat-D yang terdiri dari 4 langkah dalam menentukan, mendesain, mengembangkan, dan menyebarluaskan. Teknik pengumpulan data yang digunakan dalam proses define menggunakan teknik dokumentasi kompetensi utama (KI) dan kompetensi dasar (KD) pada kurikulum 2013. Teknik pengumpulan data yang digunakan dalam proses validasi desain teknik, observasi, survei, dan tes yang digunakan untuk mengukur kualitas produk berdasarkan ketentuan penggunaan. Hasil dari pengembangan buku teks berbasis pendidikan karakter dengan model jaminan pada siswa sekolah dasar yang telah divalidasi untuk kualitas buku sesuai dengan komponen bahan ajar, penampilan, bahasa dan grafik mencapai persentase masing-masing komponen 98,9 \%, 100\%, $96,4 \%, 94,8 \%$. Hasil observasi untuk penggunaan kegiatan komponen buku teks guru, aktivitas siswa dan tanggapan siswa menunjukkan persentase masingmasing komponen 93,5\%, 93,75\%, pernyataan sekitar 91,7\%; dan untuk hasil karakter siswa menjadi jujur, tanggung jawab, toleransi dan bekerja bersama berturut-turut, skornya adalah 4, 4, 4 dan 3.

Kata Kunci: buku teks, pendidikan karakter, model ASSURE

\section{A. Pendahuluan}

Hasil penelitian awal, mengemukakan bahwa pada pelaksanaan pembelajaran bahasa Indonesia kelas empat di sekolah dasar menunjukkan keterampilan berbicara kurang mendapat perhatian khusus. Akibatnya, penanaman pendidikan karakter terhadap siswa lingkungan lokal belum dilaksanakan. Hal ini dapat dilihat, beberapa perilaku siswa yang menunjukkan karakter kondisi secara signifikan masih ada beberapa siswa membuang sampah sembarangan, mengabaikan tugas yang diberikan guru, kurangnya sikap jujur di kelas, dan tidak responsif.

Pembelajaran model adalah langkah pertama dalam proses budaya ke dalam kelas yang dilakukan oleh tutor untuk mencapai rekor tinggi dari artefak sasaran instruksional yang 
Pendas : Jurnal IImiah Pendidikan Dasar, ISSN Cetak : 2477-2143 ISSN Online : 2548-6950 Volume III Nomor 2, Desember 2018

ditemukan dari yang berbeda. Joyce and Well (dalam Huda, 2015:73) model pembelajaran sebagai rencana pola yang dapat digunakan untuk membentuk kurikulum, adalah tentang merancang konten pembelajaran, dan memandu cara ruang proses pembelajaran pada saat yang sama di kelas atau di pengaturan yang berbeda dari apa yang disebutkan. Model pembelajaran yang dikembangkan untuk mendorong gangguan belajar lain untuk dikatakan sangat bervariasi, salah satunya adalah jenis kelas ASSURE (Analyze Learners, State Objectives, Select method, media, and materials, Utilize media and materials, Require learner and participation, Evaluate and revise) ASSURE model yang layak diformulasikan untuk kegiatan mengajar dan belajar di kelas atau banyak yang menyebut kelas ini dengan model berorientasi. Sebuah model ASSURE memiliki enam sintaks pembelajaran, antara lain: 1) analisis pembelajaran; 2) menyatakan tujuan; 3) pemilihan metode, media, dan bahan ajar; 4) penggunaan media dan material; 5) partisipasi siswa di kelas; 6) menilai dan merevisi. Berdasarkan wawancara dengan guru di awal penelitian, jenis kelas tidak pernah digunakan dalam proses pembelajaran di empat kelas sekolah dasar. Terkait dengan penggunaan penelitian yang telah dilakukan oleh Semerty jenis ruang kelas (2013) penelitian ini difokuskan pada hasil belajar siswa dengan menggunakan ASSURE jenis kelas yang dikenakan softskill kepada siswa-siswi kelas 5 SD di Badung. Hasil penelitian menunjukkan bahwa penggunaan jenis kelas lunak dibebankan keterampilan menjamin pengaruhnya terhadap hasil belajar sekolah dasar badung dalam studi sosial.

Berdasarkan penelitian yang berkaitan dengan pengajaran pertama tentang buku teks, pendidikan karakter, dan model pembelajaran ASSURE menunjukkan bahwa poin ketiga adalah kebutuhan penting untuk dikembangkan untuk menjawab permasalahan yang ditemukan oleh peneliti di SD Merjosari I Malang yang miskin. Buku teks pendidikan karakter berbasis Indonesia dengan model pembelajaran ASSURE diharapkan dapat menjadi alternatif penyelesaian masalah di sekolah dasar, sehingga pengembangan produk dari manfaat pengajaran khusus sekolah dasar Merjosari I kota malang dan unit sekolah dasar atau orang lain dan 
Pendas : Jurnal IImiah Pendidikan Dasar, ISSN Cetak : 2477-2143 ISSN Online : 2548-6950 Volume III Nomor 2, Desember 2018

dalam pembelajaran kegiatan secara umum.

\section{B. Landasan Teori}

\section{Buku Teks}

Buku teks adalah bahan yang digunakan oleh siswa untuk membantu pencapaian standar kompetensi, primer dan kompetensi yang telah ditetapkan oleh tujuan pendidikan. Sedangkan bahan ajar itu sendiri adalah seperangkat materi yang disusun secara sistematis sehingga tercipta lingkungan atau atmosfer yang memungkinkan siswa untuk belajar (Depdiknas, 2006)

Pada penelitian ini, buku teks pengajaran bahasa Indonesia kelas empat bahkan semester pertama dan kualitas pengajaran adalah buku yang memiliki empat elemen ketepatan penyusunan buku dalam suatu komponen menurut Muslich (2010: 303). Keempat sumber ini seperti, keakuratan materi, keakuratan penampilan, keakuratan penampilan, keakuratan bahasa, dan keakuratan gambar.

\section{Pendidikan Karakter}

Definisi kompleks Samani dan Hariyanto (2012:45) menjelaskan bahwa pendidikan karakter adalah proses memberi kepada siswa yang mengarah untuk dapat menyelesaikan yang tanpa ciri di dimensi hati, berpikir, berolahraga, dan menciptakan dan karsa. Pendidikan karakter adalah nilai-nilai transformasi kehidupan untuk dikembangkan dalam kepribadian seseorang sehingga menjadi satu dalam perilaku kehidupan seseorang (Gaffar dalam Kesuma, 2012: 5). Berdasarkan beberapa penjelasan di atas, kita dapat menyimpulkan bahwa pendidikan karakter adalah proses pemberian kepribadian atau nilai kepada siswa untuk menjadi karakter manusia. Kurikulum 2013 memiliki aspek karakter yang digunakan dalam pengembangan siswa.

Jujur adalah perilaku yang didasarkan pada upaya menjadikan dirinya sebagai orang yang dapat dipercaya dalam kata, tindakan, dan pekerjaan. Tanggung jawab adalah sikap dan tingkah laku seseorang untuk melakukan tugas dan tanggung jawab mereka, yang harus dia lakukan, dengan diri kita sendiri, masyarakat, sehingga mereka adalah lingkungan, sosial dan budaya), negara dan satusatunya dewa. Toleransi adalah sikap dan tindakan yang menghargai perbedaan agama, suku, etnis, pendapat, sikap, dan perilaku orang 
Pendas : Jurnal IImiah Pendidikan Dasar, ISSN Cetak : 2477-2143 ISSN Online : 2548-6950 Volume III Nomor 2, Desember 2018

lain yang berbeda dari dirinya sendiri. Bekerja bersama bekerja sama dengan orang lain untuk mencapai tujuan bersama dengan berbagi tugas dan saling membantu dengan tulus.

\section{Model ASSURE}

Model ASSURE (menganalisis pelajar, standar dan obyektif, memilih strategi, teknologi, media dan material, memanfaatkan teknologi, media dan material, membutuhkan partisipasi pembelajar, mengevaluasi dan merevisi) adalah model pembelajaran yang konsep perencanaan di kelas dengan memadukan teknologi dan media untuk mendukung dan meningkatkan pengajaran. Model ASSURE adalah model pembelajaran yang mendesain minat untuk belajar bagi siswa yang mulai dari menganalisis minat siswa, mempresentasikan materi berdasarkan analisis minat siswa, umpan balik, mengukur pemahaman siswa, hingga evaluasi. Smaldino, Lowther, Russell menunjukkan bahwa sintaks (2011) menyusun pembelajaran berdasarkan model ASSURE sebagai berikut
Untuk kegiatan ini guru merencanakan pembelajaran berdasarkan kebutuhan siswa dengan mempertimbangkan 3 faktor, :1) karakteristik umum yang meliputi: usia, jenis kelamin, kelas, budaya, atau sosial ekonomi; 2) kompetensi dasar spesifik. Untuk mengidentifikasi keterampilan dasar siswa tertentu, guru dapat membuat dengan cara formal dan informal; 3) gaya belajar.

b.) Standar dan tujuan negara Standar dan tujuan adalah untuk pemilihan strategi dasar, teknologi, dan media. dasar untuk penilaian. dasar untuk harapan belajar siswa.

c.) Pilih strategi, teknologi, media, dan material

Pada strategi pemilihan, teknologi, dan materi yang patut dipertimbangkan adalah strategi harus berpusat pada guru dan siswa mempertimbangkan sumber daya yang tersedia dan karakteristik siswa, sementara materi yang disampaikan bias dengan memilih materi yang tersedia, mengubah materi yang tersedia atau menyusun materi baru yang tujuan dari belajar bisa diraih.
a.) Analisis Pelajar
d.) Memanfaatkan teknologi, media, dan material 
Pendas : Jurnal IImiah Pendidikan Dasar, ISSN Cetak : 2477-2143 ISSN Online : 2548-6950 Volume III Nomor 2, Desember 2018

Penggunaan teknologi, perencanaan media dan bahan-bahan yang dibutuhkan: 1) pratinjau sehingga apa yang sesuai dengan tujuan penelitian atau tidak, 2) bahan yang disiapkan yang mendukung pengajaran, c mempersiapkan lingkungan yang akan dipakai dalam pembelajaran, mempersiapkan siswa, mempersiapkan pengalaman belajar
e.) Membutuhkan
partisipasi
pembelajar

Setelah berpartisipasi dalam pengajaran diberi umpan balik daripada informatif untuk memahami sejauh mana tujuan pembelajaran dapat dicapai.

f.) Evaluasilah dan revisi

Evaluasi bertujuan untuk menilai sejauh mana tujuan pembelajaran dapat dicapai oleh siswa dan untuk strategi, teknologi, dan media telah berjalan efektif dan siswa tertarik atau tidak. Sementara revisi berusaha meningkatkan hasil studi dan merevisi strategi, teknologi, dan media.

\section{Metode Penelitian}

Data diperoleh melalui proses tahap pengembangan mendefinisikan dan fase desain. Selama tahap persiapan ini mendefinisikan data yang diperoleh dalam bentuk perumusan KI (Kompetensi Inti) dan KD (Kompetensi Dasar), sedangkan pada perancangan data diperoleh dari validator penilaian tim untuk mengukur kualitas buku-buku teks. Kualitas data yang diperoleh dari pengembangan tahap berkembang, nilai skor yang diberikan oleh validator dan mengharapkan pengguna. Mengumpulkan data yang meliputi teknik validasi yang digunakan, observasi, survei dan tes.

Analisis data dalam penelitian ini dilakukan semacam statistik deskriptif. Analisis deskriptif berfungsi untuk menyediakan, menjelaskan atau menyediakan informasi. Seperti pendapat Arikunto (2009:268), dikatakan bahwa penelitian yang menggunakan analisis deskriptif kualitatif adalah evaluasi penelitian yang dilakukan untuk mengevaluasi sejauh mana setinggi variabel tersebut sudah sesuai dengan patokan yang baik sudah ditentukan. Jenis penelitian menggunakan penelitian pengembangan dan pengembangan penelitian. Desain penelitian berorientasi pada model empat-D yang terdiri dari empat fase menentukan, merancang, mengembangkan, dan menyebar Menurut Thiagarajan, Semmel dan 
Pendas : Jurnal IImiah Pendidikan Dasar, ISSN Cetak : 2477-2143 ISSN Online : 2548-6950 Volume III Nomor 2, Desember 2018

Semmel (1947:3). Namun kami membatasi hanya untuk tahap perkembangan. Jadi teks yang dikembangkan hanya menggunakan sekolah saja, tanpa dessimintae di sekolah lain

Fase penelitian di SD Merjosari II Kota Malang. Ruang kelas studi sampel terbatas pada percobaan 15 siswa dan luas untuk uji coba 30 siswa. Tanggal uji coba terbatas dilaksanakan pada 23 Agustus 2018. Sementara uji coba luas dilaksanakan pada 9 September 2018 di empat kelas kelas Sekolah Dasar Merjosari II Kota Malang. Pada masing-masing ujicoba percontohan yang terdiri dari tahap dan pasca tes peran penelitian sebagai observer di ruang kelas SD Merjosari II Kota Malang.

\section{Hasil dan Pembahasan}

Dari penulisan buku ini dan rumusan mengajar draft I sesuai dengan komponen oleh feasibilty sementara itu. Selain itu, dipertimbangkan pendapat dan saran dari para ahli dan peneliti lainnya. Persiapan buku ajar ini sejalan dengan persiapan buku teks sesuai dengan sementara. Buku ajar itu dikembangkan untuk melengkapi buku teks yang digunakan siswa. Permasalahan apa yang muncul dilapangan karena buku ajar 2013 yang digunakan siswa dan karakter suatu materi adalah pada buku teks perlu dilengkapi baik dari segi kualitas dan kuantitas.

Validasi yang saya temukan persentasenya sebesar $73,85 \%$ itu dapat dikatakan layak digunakan dengan sedikit revisi. Setelah revisi draft I maka revisi menghasilkan draft II yang kemudian divalidasi kembali oleh masing-masing validator, persentase validasi draft II 97,9\% ini dapat digolongkan layak digunakan. Pernyataan sesuai dengan pedoman buku teks BSNP yang merupakan hasil pengembangan yang baik ditentukan untuk kualitas produk pembangunan. Kualitas produk buku teks pengembangan mengacu pada kualitas pembuatan buku dengan cara mencetak Depdiknas (2007: 21) yaitu dalam hal materi, penyajian, bahasa, dan grafik, sajian tersebut dapat dilihat pada tabel berikut,

Tabel 1. Hasil validasi draf buku

\begin{tabular}{|c|c|c|c|c|c|c|c|}
\hline \multirow[b]{2}{*}{ No } & \multirow{2}{*}{$\begin{array}{c}\text { Kriteria buku } \\
\text { teks }\end{array}$} & \multicolumn{6}{|c|}{ Hasil Validator } \\
\hline & & $\begin{array}{l}\text { hasil } \\
\text { Draf I }\end{array}$ & $\begin{array}{c}\text { Hasil } \\
\text { Draf II }\end{array}$ & $\begin{array}{l}\text { persentase } \\
\text { draf I }\end{array}$ & $\begin{array}{l}\text { persentase } \\
\text { draf II }\end{array}$ & $\begin{array}{c}\text { Kategori } \\
\text { draf I }\end{array}$ & $\begin{array}{l}\text { Kategori draf } \\
\text { II }\end{array}$ \\
\hline 1 & materi & 33 & 39 & $82,5 \%$ & $98,5 \%$ & Sangat layak & Sangat layak \\
\hline 2 & Penyajian & 25 & 38 & $62,5 \%$ & $100 \%$ & Layak & Sangat layak \\
\hline 3 & Kebahasaann & 26 & 27 & $92,9 \%$ & $96,4 \%$ & Sangat layak & Sangat layak \\
\hline 4 & Kegrafikaan & 23 & 38 & $57,5 \%$ & $95 \%$ & Layak & Sangat layak \\
\hline & Total & 107 & 142 & $295,4 \%$ & 389,9 & Layak & Sangat layak \\
\hline & & & & $73,85 \%$ & $97,9 \%$ & Layak & Sangat layak \\
\hline
\end{tabular}

Kegiatan belajar dengan menggunakan buku teks dapat 
Pendas : Jurnal IImiah Pendidikan Dasar, ISSN Cetak : 2477-2143 ISSN Online : 2548-6950 Volume III Nomor 2, Desember 2018

membantu guru dalam proses bahan ajar. Dapat dilihat bahwa persentase aktivitas guru uji coba terbatas pada kelas empat mendapatkan hasil $82,5 \%$ dengan sangat aktif sedangkan kriteria uji coba pada luas aktivitas guru di kelas empat mendapat persentase pecahan $92,5 \%$ dengan kriteria sangat aktif. . Hal ini sesuai dengan pernyataan dari Arikunto (2010: 40) dari kreditnya mencakup aktivitas guru dalam interval $81 \%$ $100 \%$ dengan kriteria sangat baik. Hal ini dapat dilihat dari tabel dibawah ini

Tabel 2. Aktivitas guru

\begin{tabular}{|c|c|c|c|c|c|c|c|}
\hline \multirow[t]{2}{*}{ No } & \multirow[t]{2}{*}{ komponen } & \multicolumn{3}{|c|}{ Uji coba terbatas } & \multicolumn{3}{|c|}{ Uji coba luas } \\
\hline & & P1 & P2 & \begin{tabular}{|l} 
Rets- \\
rats
\end{tabular} & P1 & P2 & Rets-rsta \\
\hline $\mathbf{A}$ & \multicolumn{4}{|l|}{ Kegiatan pembuka (10 menit) } & & & \\
\hline 1. & Melakukan kegiatan pembuka & 4 & 3 & 3,5 & 4 & 3 & 3,5 \\
\hline 2. & Menyiapkan siswa & 3 & 3 & 3 & 4 & 4 & 4 \\
\hline 3. & Menyampaikan Tujuan Pembelajaran & 3 & 3 & 3 & 3 & 3 & 3 \\
\hline B & \multicolumn{4}{|l|}{ Kegiatan Inti (55 menit) } & & & \\
\hline 1. & $\begin{array}{l}\text { Menjelaskan materi yang terdapat } \\
\text { dalam buku teks bahasa Indonesia } \\
\text { menunjukkan didepan kelas }\end{array}$ & 4 & 3 & 3,5 & 4 & 4 & 4 \\
\hline 2. & \multicolumn{2}{|l|}{$\begin{array}{l}\text { Memberikan petunjuk dan } \\
\text { memberikan kesempatan pada siswa } \\
\text { untuk menyimak materi pada buku } \\
\text { teks }\end{array}$} & 3 & 3 & 4 & 4 & 4 \\
\hline 3 & $\begin{array}{l}\text { partisiapagi altif sisura melalui } \\
\text { interaksi guru, sisna dan sumber } \\
\text { belajar. }\end{array}$ & 3 & 3 & 3 & 4 & 4 & 4 \\
\hline 4 & $\begin{array}{l}\text { melibatkan giavu mencari informaai } \\
\text { yang luas dan dalam tentang materi } \\
\text { yang dipelajaxi }\end{array}$ & 4 & 3 & 3,5 & 4 & 4 & 4 \\
\hline 5. & $\begin{array}{l}\text { Membagi kelompok siava untulk } \\
\text { mendiakusikan latihan soal materi } \\
\text { dalam buku ajar bahasa Indonesia }\end{array}$ & 4 & 3 & 3,5 & 4 & 4 & 4 \\
\hline 6. & $\begin{array}{l}\text { Setian kelompok diberi kesempatan } \\
\text { membacakan basil diskusinya di } \\
\text { depan kelan }\end{array}$ & 4 & 4 & 4 & 3 & 3 & 3 \\
\hline $\mathbf{C}$ & \multicolumn{4}{|l|}{ Kegiatan penutup (15 menit) } & & & \\
\hline 1. & Melakukan kegiatan akhir & 3 & 3 & 3 & 4 & 3 & 3.5 \\
\hline \multicolumn{2}{|c|}{ Total } & 35 & 31 & 33 & 38 & 36 & 37 \\
\hline \multicolumn{2}{|c|}{ Persentase (\%) } & 87,5 & 77,5 & 82,5 & 95 & 90 & 93,5 \\
\hline \multicolumn{2}{|c|}{ kriteria } & \multicolumn{3}{|c|}{ Baik sekali } & \multicolumn{3}{|c|}{ aik sekali } \\
\hline
\end{tabular}

Penggunaan buku teks dapat membantu siswa belajar dalam proses kegiatan di kelas. Hal ini terbukti bahwa aktivitas siswa dalam uji coba terbatas pada ruang kelas $87,5 \%$ hasil sangat aktif dalam uji coba kegiatan luas dari kelas empat kelas memperoleh persentase $93,75 \%$ pada yang sangat aktif. Dan respon siswa ketika menggunakan buku teks Bahasa Indonesia di persidangan terbatas beberapa sangat $88 \%$ pada sangat wajar, maka di uji coba hasil respon luas siswa $91,7 \%$ pada sangat wajar

Tabel 3. Aktivitas Siswa

\begin{tabular}{|c|c|c|c|c|c|c|c|}
\hline \multirow[t]{2}{*}{ No } & \multirow[t]{2}{*}{ Komponen } & \multicolumn{3}{|c|}{ Uji coba terbatas } & \multicolumn{3}{|c|}{ Uji coba luas } \\
\hline & & Pl & P2 & $\begin{array}{l}\text { Rata- } \\
\text { rata }\end{array}$ & Pl & P2 & $\begin{array}{l}\text { Rata- } \\
\text { rata }\end{array}$ \\
\hline 1 & $\begin{array}{l}\text { Respon siswa saat materi disampaikan } \\
\text { guru }\end{array}$ & 4 & 4 & 4 & 4 & 4 & 4 \\
\hline 2 & $\begin{array}{l}\text { Respon siswa saat memahami materi yang } \\
\text { disampaikan guru }\end{array}$ & 3 & 3 & 3 & 4 & 4 & 4 \\
\hline 3 & $\begin{array}{l}\text { Respon siswa saat mengerjakan latihan } \\
\text { soal dari buku ajar }\end{array}$ & 4 & 3 & 3,5 & 4 & 4 & 4 \\
\hline \multirow[t]{4}{*}{4} & $\begin{array}{l}\text { Waltu yang diperlukan siswa untuk } \\
\text { menerima/menyimak materi dan } \\
\text { mengeriakan latihan sol. }\end{array}$ & 3 & 4 & 3,5 & 3 & 3 & 3 \\
\hline & Total & 14 & 14 & 14 & 15 & 15 & 14 \\
\hline & Persentase & 87,5 & 87,5 & 87,5 & 93,75 & 93,75 & 93,75 \\
\hline & kriteria & \multicolumn{3}{|c|}{ Baik sekali } & \multicolumn{3}{|c|}{ Baik sekali } \\
\hline
\end{tabular}

\section{E. Kesimpulan}

Dari penelitian, sehingga dapat disimpulkan bahwa proses pengembangan produk melalui tiga putaran tahap pendefinisian, perancangan, dan pengembangan tahap pendefinisian meliputi lima langkah dasar yang harus ditempuh, yaitu analisis akhir akhir, analisis karakteristik siswa, analisis konsep, analisis tugas, tujuan pembelajaran dan analisis. Desain panggung meliputi penulisan dan perumusan 
Pendas : Jurnal IImiah Pendidikan Dasar, ISSN Cetak : 2477-2143 ISSN Online : 2548-6950 Volume III Nomor 2, Desember 2018

draft buku kebanggaan dan validasi. Tahapan perkembangan itu meliputi revisi hasil rancangan validasi, validasi buku pedoman II, revisi hasil validasi draft II, uji coba terbatas dan uji coba yang luas.

Kualitas buku teks dinilai dari segi produk dan dalam hal penggunaannya di kelas. Dari segi produk, dianggap pengajaran materi, penyajian, kebahasaan, dan kegrafikaan. Komponen materi mencetak skor 39 dengan 97,5\%. penyajian dari skor 38 dengan 95\%. Komponen kebahasaan skor 27 dengan $\quad 96,4 \%$. Komponen kegrafikaan mencetak skor 38 dengan 95\%. Dari penilaian validator diperoleh persentase 97,9\%, kategori sangat layak.

Untuk hasil kualitas buku karakter yang diajarkan dalam hal penggunaan di kelas ditentukan oleh aktivitas guru, aktivitas siswa, respon siswa dan hasil belajar siswa. Dari uji coba kegiatan terbatas, $82,5 \%$ guru memiliki persentase. Siswa mendapat $87,5 \%$ aktivitas. Siswa mendapatkan hasil 85 karakter jujur memiliki skor 2,9; bertanggung jawab memiliki skor 2,8; toleransi memiliki skor 3 dan bekerja bersama skor 2,6.
Hasil dari uji coba yang luas yaitu aktivitas guru di ruang kelas memiliki persentase $93,5 \%$, aktivitas siswa dari kelas empat mendapat persentase $93,75 \%$,. Respon dari siswa kelas empat mendapatkan hasil 91,7. dan untuk hasil karakter siswa menjadi jujur, tanggung jawab, toleransi dan bekerja bersama berturut-turut, skor adalah 4, 4, 4 dan 3

Penelitian ini perlu mengejar perkembangan buku ajar karena hasil penelitian belum pada tahap akhir, yaitu penyebaran. Penyempurnaan buku ini perlu diajarkan, mudah dipahami bahwa seharusnya tidak hanya di SDN Merjoasari I Malang, tetapi juga bisa dipahami oleh semua sekolah dasar di Indonesia. Saran bagi siswa untuk menggunakan buku teks siswa, sehingga dapat memenuhi kebutuhan siswa dalam pengalaman mereka. Saran untuk guru sekolah dasar untuk menyusun dan mengatur subjek mereka sendiri sesuai dengan karakteristik dan kebutuhan peserta.

Saran untuk buku teks peneliti lain, bahwa dalam penyusunan buku ajar harus melihat pengguna karakteristik, menyesuaikan indikator $\mathrm{KI}$ (kompetensi utama) dan KD (kompetensi dasar) memilih ilustrasi yang dikenal oleh siswa, menulis 
Pendas : Jurnal IImiah Pendidikan Dasar, ISSN Cetak : 2477-2143 ISSN Online : 2548-6950

Volume III Nomor 2, Desember 2018

materi yang disampaikan hanya tetapi masih mengandung $\mathrm{KI}$ (utama kompetensi) dan KD (kompetensi dasar), dan mempersiapkan buku teks sesuai standar BSNP

\section{DAFTAR PUSTAKA}

Arikunto. 2009. Dasar-Dasar Evaluasi Pendidikan. Jakarta: Bumi Aksara.

Arikunto, Suharsimi. 2006. Prosedur Penelitian: Suatu Pendekatan Praktik. Jakarta: PT Rineka Cipta.

Arikunto, Suharsimi,.2010. Metodologi Penelitian. Jakarta: PT Bumi Akasara.

Depdiknas. 2013. Panduan Pengembangan Bahan Ajar. Jakarta:Depdiknas. .

Huda, Miftahul. 2015. Model- model Pengajaran Pembelajaran (Isu-isu metodis dan Paradigmatis. Malang: Pustaka Pelajar.

Muslich, Mansur. 2010. Textbook Writing:Dasar-Dasar

Pemahaman.Penulisan dan Pemakaian Buku Teks. Jogjakarta:Ar-Ruzz Media.

Samani, Muchlas, dan Hariyanto. 2012. Konsep dan Model Pendidikan Karakter. Bandung: PT Remaja Rosdakarya.

Semerty, Ni Made Dhyas, I Gd. Meter, M.G. Rini Kristiantari. 2013. Model Pembelajaran ASSURE Bermuatan Soft Skill Berpengaruh Terhadap Hasil Belajar IPS Siswa Kelas V SD Negeri Gugus IX Abiansemal Badung. Jurnal
Universitas Pendidikan Ganesha, Singaraja.

Smaldino, LOwther, Russel. 2011. Instructional Technology \& Media For Learning. Jakarta: Kencana Pernada Media Group.

Thiagarajan, Semmel.1947. Instructional Development for Training Teacher of Expectational Children. Minnesota: Indiana University. 